\title{
Demographic characteristics of owned dogs and cats of Votorantim, São Paulo State, Brazil
}

\author{
Características demográficas de cães e gatos domiciliados em \\ Votorantim, Estado de São Paulo, Brasil \\ Oswaldo Santos Baquero ${ }^{\mathrm{I}}$ II $^{*}$ Evelyn Nestori Chiozzotto ${ }^{\text {II }}$ \\ Rita de Cassia Maria Garcia ${ }^{I I}$ Marcos Amaku ${ }^{I}$ Fernando Ferreira ${ }^{I}$
}

\begin{abstract}
A two-stage cluster sample design was used to estimate population parameters of dogs and cats of the urban area of Votorantim, São Paulo State, Brazil, to support the planning and implementation of population management programs for companion animals. For dogs, the total and density estimates were 27,241 dogs (95\% confidence interval $[C I]=23,903-30,578)$ and 951 dogs $\mathrm{km}^{-2}(95 \% \mathrm{CI}=835-1,068)$, respectively. For cats, these estimates were 5,579 cats (95\% CI=3,595-7,562) and 195 cats $\mathrm{km}^{-2}$ (95\% CI=126-264). Cost was the most prevalent reason for not sterilizing the animals $(33 \%, 95 \%$ CI $=23 \%$ $44 \%$, Deff $=6.1$ ). The percentage of interviewees that expressed reasons for abandoning their animals was equal to $9(95 \%$ $C I=5-13$, Deff=2.1). Other estimates were obtained, including indirect estimates of abandonment. The estimates associated with abandonment suggest that the prevalence of this phenomenon can significantly affect population dynamics. Distribution of dogs per household can be used to construct hypothetical populations and to validate estimation procedures. The estimates generated allow parameterizing mathematical models and constructing population management indicators.
\end{abstract}

Key words: dogs, cats, population management, demography, sampling, estimates.

\section{RESUMO}

Um desenho amostral por conglomerados em dois estágios foi usado para estimar parâmetros populacionais de cães e gatos da área urbana de Votorantim, São Paulo, Brasil, visando dar suporte ao planejamento e implementação de programas de manejo populacional de animais de companhia. Para os cães, as estimativas do total e da densidade foram 27,241 cães $(95 \%$ intervalo de confiança $[C I]=23,903-30,578)$ e 951 cães $\mathrm{km}^{-2}(95 \%$ $C I=835-1,068)$, respectivamente. Para os gatos, essas estimativas foram 5,579 gatos (95\% CI=3,595-7,562) e 195 gatos $\mathrm{km}^{-2}(95 \%$
$C I=126-264)$. O custo foi a razão mais prevalente para não esterilizar os animais (33\%, 95\% CI=23\%-44\%, Deff $=6.1)$. A porcentagem de entrevistados que relatou razões para abandonar seus animais foi igual a nove (95\% CI=5-13, Deff $=2.1)$. Outras estimativas foram obtidas, incluindo estimativas indiretas de abandono. As estimativas associadas ao abandono sugerem que a prevalência desse fenômeno pode afetar significativamente a dinâmica populacional. A distribuição de cães por domicílio pode ser usada para construir populações hipotéticas e validar procedimentos de estimação. As estimativas geradas permitem a parametrização de modelos matemáticos e a construção de indicadores de manejo populacional.

Palavras-chave: cães, gatos, manejo populacional, demografia, amostragem, estimativas.

\section{INTRODUCTION}

Problems associated with companion animals are the result of individual and collective human behavior (FOURNIER; GELLER, 2004). Despite decades of efforts to manage dog and cat populations, the persistence of these problems (CARTER, 1990) has brought the effectiveness of such efforts into question (CARTER, 1990; SCARLETT, 2008).

Demographic characteristics determine the dynamics of zoonoses and other diseases in animal populations (THRUSFIELD, 2007) and currently, demographic studies of dogs and cats are a guiding component for population management in different

\footnotetext{
IDepartamento de Medicina Veterinária Preventiva e Saúde Animal, Faculdade de Medicina Veterinária e Zootecnia (FMVZ), Universidade de São Paulo (USP), São Paulo, SP, Brasil.

IIInstituto Técnico de Educação e Controle Animal (ITEC), Rua Marechal Olimpio Moura Filho, 64, Vila São Francisco, 05352-080, São Paulo, SP, Brasil. E-mail: oswaldosant@gmail.com. "Corresponding author.
} 
parts of the world (SLATER et al., 2008; DOWNES et al., 2009; ACOSTA-JAMETT et al., 2010; CANATTO et al., 2012; PULCZER et al., 2013).

The estimation of demographic parameters is fundamental for assessing health programs, such as vaccination campaigns (vaccination coverage). Moreover, demographic parameters allow simulating the potential effects of interventions and building effectiveness indicators, two essential components to evaluate interventions for population management (FERREIRA, 2010).

Although useful, few studies have parameters that can be used to simulate the occurrence of diseases in animal populations or in the evaluation of health programs (GARCIA, 2009; DAVLIN; VONVILLE, 2012; PULCZER et al., 2013). Thus, this study aimed to estimate the demographic parameters relevant to the population dynamics of owned dogs and cats residing in the urban area of Votorantim, São Paulo State, Brazil using data from a sample survey for this purpose.

\section{MATERIALS AND METHODS}

\section{Study site}

The city of Votorantim is located in the Southwest of the state of São Paulo, Brazil. The city has an area of $183,517 \mathrm{~km}^{2}$, of which $28.63 \mathrm{~km}^{2}$ is urban IBGE (CENSUS, 2010). There are a total of 108,809 inhabitants, and 104,659 of them reside in the urban area. This urban area has 114 census tracks and 30,800 households, with a mean of 222 households per IBGE census track (CENSUS, 2010).

\section{Population parameters}

Proportion of households with dogs or cats and total and mean number of animals (dogs, cats and both species) per household were estimated. For both species it was also estimated the gender ratio, mean age, proportion of sterilized animals, proportion of semirestricted animals, mode of acquisition, mean number of pups born in the previous 12 months and fate of animals that had lived in the household in the previous 12 months. Reasons for not sterilizing the household animals and for abandoning them were also estimated.

\section{Data collection}

Questionnaires completed by interviewers were used to collect data. Response options were closed and multiple choice; for some questions, an open option was added. After the general structuring of the questionnaire, five training sessions and a pilot study were performed to evaluate the operational capacity of the team and to test the instrument in the field. Eight employees of the Center for Zoonosis Control of Votorantim (Centro de Controle de Zoonoses de Votorantim) participated in these sessions, of which four were selected to become interviewers at the end of the program. The sessions aimed to detect confusing questions and questions that could be included in the questionnaire and to simulate interviews to adequately format the questionnaire and to optimize the application time. Data were collected with the final version of the questionnaire, between october and december of 2011.

\section{Sample design}

Target and study populations: the target population was the set of households in the urban area of the municipality of Votorantim, whereas the the study population was the set of households in the urban area of Votorantim, from october to december 2011.

Sampling frame: list of census tracts (primary sampling units) and private and collective households (secondary sampling units) in the urban area, generated by the Brazilian Institute of Geography and Statistics (Instituto Brasileiro de Geografia e Estatística - IBGE) in the 2010 census IBGE (CENSUS, 2010).

Selection plan: five census tracts were selected with probability proportional to size and with replacement. One hundred and five households were selected in each census tract using a systematic sampling. The measure of the census tract size was the number of households.

Sample size: the sample size was calculated considering the operational capacity of the Center for Zoonoses Control of Votorantim. Taking in to account the difficulty to include more than a few census tracks due to displacement limitations and the expected duration of interviews, it was determined that including 5 census tracks, a mean of 105 households per census track could be visited. Once completed the field research, a mean of 103 households per census track were visited.

\section{Statistical analysis}

All variable categories were considered, but for certain variables with multiple response options, only the more frequent responses will be presented. Assuming that the size of the census tracts is correct and that there were no changes in the census tract size between sample selection and data collection, household selection was equiprobabilistic; therefore, the sample was self-weighted (UNITED NATIONS, 2005). Base estimator was the Horvitz-Thompsom. 
Variances were estimated using the linearization method based on a Taylor series (LUMLEY, 2010). For each estimate, the effect of the study design was expressed by the estimated design effect Deff (estimated variance divided by the calculated variance when considering the design as a simple random design) (LUMLEY, 2010).

Software programs used

The analyses were performed in $\mathrm{R}(\mathrm{R}$ CORE TEAM, 2015) using the package capm 0.8.0 (SANTOS BAQUERO et al., 2015).

\section{RESULTS}

Of the 515 households visited, the interview could be performed in 450 households, which corresponded to a response rate of $87 \%$. Closed households accounted for $12 \%$, and refusals for $1 \%$. Households percentage with dogs or cats was of $56 \%$ $(95 \% \mathrm{CI}=52 \%-60 \%$, Deff $=0.8)$. The total and mean numbers of dogs per household were higher than the corresponding values for cats (Table 1). Based on point estimates and CIs, the densities of dogs and cats in the urban area were of 951 dogs $\mathrm{km}^{2}(95 \% \mathrm{CI}=835$ $1,068)$ and 195 cats $\mathrm{km}^{2}(95 \% \mathrm{CI}=126-264)$. When classifying the households according to the number of dogs (cats) that they contained, the higher this number, less frequent the households (Figure 1).

The male/female ratios of dogs $(0.87$, $95 \% \mathrm{CI}=0.57-1.16)$ and cats $(0.98,95 \% \mathrm{CI}=0.67$ 1.22) were not different than 1 . The percentage of neutered and spayed dogs were equal to $17 \%(95 \%$ $\mathrm{CI}=11 \%-24 \%$, Deff $=1.3)$ and $23 \%$ (95\% CI $=13 \%$ $33 \%$, Deff $=3.4)$. The percentage of neutered and spayed cats were equal to $56 \%(95 \% \mathrm{CI}=31 \%-80 \%$, Deff $=2.2)$ and $23 \%(95 \% \mathrm{CI}=51 \%-88 \%$, Deff $=1.7)$. The mean ages were 5.27 years $(95 \% \mathrm{CI}=4.84-5.71$, Deff $=1.17)$ for dogs and 3.87 years $(95 \% \mathrm{CI}=3.20$ 4.54 , Deff $=0.76$ ) for cats.

Table 1 - Total and mean numbers of dogs and cats per household that are or were present in the previous 12 months in the households interviewed. Votorantim, São Paulo state, Brazil, 2011.

\begin{tabular}{llc}
\hline Variable & Estimate $(95 \%$ CI $)$ & $\begin{array}{c}\text { Design } \\
\text { effect }\end{array}$ \\
\hline Total dogs & $27,241(23,903-30,578)$ & 1.2 \\
Total cats & $5,579(3,595-7,562)$ & 1 \\
Mean dogs per household & $0.88(0.78-0.99)$ & 1.2 \\
Mean cats per household & $0.18(0.12-0.25)$ & 1 \\
\hline
\end{tabular}

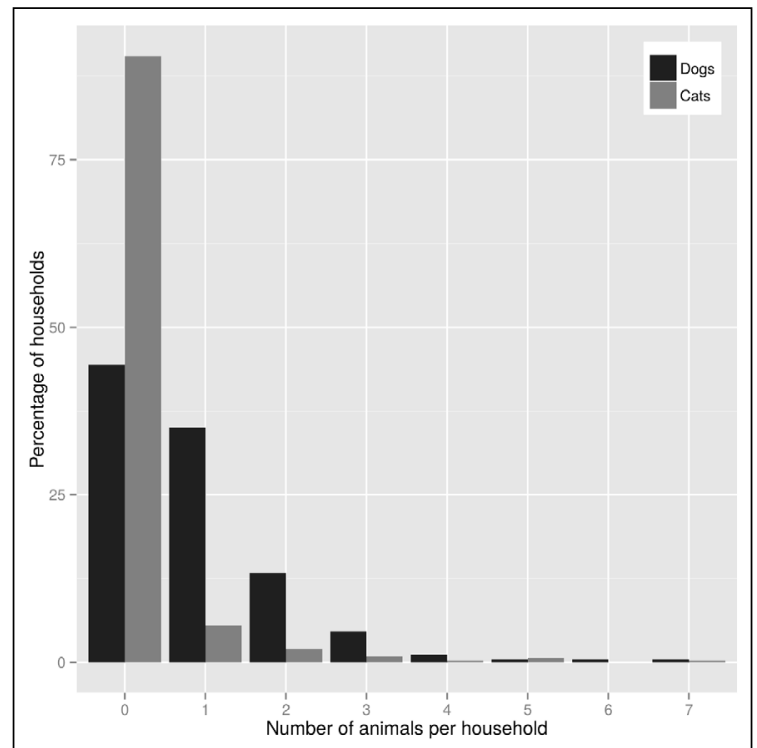

Figure 1 - Distribution of total dogs and cats per household, including those that are or were present in the previous 12 months at the households interviewed. Votorantim, São Paulo State, Brazil, 2011.

In the 12 months before the interview, a total of $28 \mathrm{dogs}$ and 12 cats were born in the households interviewed, and the estimates for these totals were $1,881(95 \% \mathrm{CI}=286-3,476$, Deff $=1.4)$ and $902(95 \%$ $\mathrm{CI}=0-2,330$, Deff $=2.1$, respectively. Percentages of semi-restricted dogs and cats were equal to $17 \%(95 \%$ $\mathrm{CI}=9 \%-26 \%$, Deff $=5.2)$ and $56 \%(95 \% \mathrm{CI}=29 \%$ $83 \%$, Deff $=6.2$ ). The main mode of acquisition for both species was receiving the animal from another individual (Table 2). In the 12 months before the interview, $7.32 \%(95 \% \mathrm{CI}=5.57 \%-9.06 \%$, Deff $=0.46)$ of dogs and $4.82 \%(95 \% \mathrm{CI}=0.80 \%-8.85 \%$, Deff $=0.75)$ of cats left interviewees' households. Death, adoption and disappearance were reported fates.

Cost was the most prevalent reason for not sterilizing the animals $(33 \%, 95 \% \quad \mathrm{CI}=23 \%$ $44 \%$, Deff $=6.1$, however, other reasons were also reported ("wants offspring", "lack of time", "it is cruelty", "animal too young", "does not know", "does not answered", "it may die", "can get diseased", and "veterinarian recommendation"). Percentage of interviewees that expressed reasons for abandoning their animals was equal to $9 \%(95 \% \mathrm{CI}=5 \%-13 \%$, Deff $=2.1)$ and aggressiveness was the main reason for abandoning their animals, followed by diseases, behavioral problems other than aggressiveness and moving. Other reasons represented less than $0.5 \%$ of answers.

\section{DISCUSSION}

Samples collected enabled the calculation of the point estimate, the CI and the Deff for 
Table 2 - Sources of animals that are or were present in the previous 12 months in the households interviewed. Votorantim, São Paulo state, Brazil, 2011.

\begin{tabular}{llclc}
\hline Variable & ----1--- Dogs & & & \\
& $\%(95 \% \mathrm{CI})$ & $\begin{array}{c}\text { Design } \\
\text { effect }\end{array}$ & $\%(95 \% \mathrm{CI})$ & $\begin{array}{c}\text { Design } \\
\text { effect }\end{array}$ \\
\hline Adopted & $10(9-12)$ & 0.3 & $26(19-33)$ & 0.6 \\
Purchased & $16(11-22)$ & 2.2 & $1(0-3)$ & 1 \\
Found & $7(13-13)$ & 3.8 & $12(4-19)$ & 1.1 \\
Gift & $57(49-64)$ & 2.3 & $39(28-50)$ & 1.1 \\
Born at home & $10(5-15)$ & 2.9 & $23(11-34)$ & 2.1 \\
\hline
\end{tabular}

population parameters. As in studies performed in other locations, there were more households with dogs than with cats (SLATER et al., 2008; DOWNES et al., 2009; CANATTO et al., 2012).

Low mean ages of companion animals are considered a consequence of rapid population turnover and low life expectancy (KITALA et al., 2001). In Votorantim, improvements in responsible ownership can increase the life expectancy and decrease the population turnover and these should be reflected in higher mean ages.

The possibility of including information bias when asking for the restriction degree of animals has been reported (CANATTO et al., 2012). To prevent responses due to social desirability and to consider the restriction of movement and supervision, interviewees were asked if their animal "liked to go out on the street alone". The estimated proportions obtained from the responses for this question are potential indicators of responsible ownership and decreases on them might be mediated by purposeful interventions to reduce the number of stray animals in the streets.

Although there are studies that report purchase as the most common mode of acquisition of dogs and cats (PATRONEK et al., 1996), free acquisition was more frequent for both species in Votorantim, which corroborates other studies (KITALA et al., 2001; GARCIA, 2009; ACOSTAJAMETT et al., 2010; CANATTO et al., 2012).

The most frequent reason for not sterilizing animals was the cost of the procedure. Thus, the importance of a free program for mass sterilization must be analyzed in the sectors involved with dog and cat population management in the city. The remaining reasons were consistent with ignorance of the implications of the procedure. Although these reasons were not prevalent individually, jointly, they represented a contingent with the potential to significantly modify the proportion of sterilized animals.
The reasons that would lead interviewees to abandon their own animals represented hypothetical situations. However, individuals who surrendered their animals to shelters also reported these reasons or potential risk factors (MILLER et al., 1996; NEW et al., 1999, 2000; DIESEL et al., 2008; CASEY et al., 2009; ELLIOTT et al., 2010), suggesting that interviewees can identify in advance intolerable situations in their cohabitation with their animals. Thus preventive programs focused on the preacquisition of animals and on ethological approaches to understand and manage some behaviors, may help to reduce abandonment rates.

Sample size and composition were not calculated following any statistical procedure and this might arise concerns about the representativeness of the sample. However, the selection of census tracks and households followed a probabilistic procedure that allowed the construction of unbiased estimates from sample data. Thus, sample size and composition defined by convenience were not a concern for the accuracy of the data and any effect of the sample size and composition on the precision of the estimates was taken into account in the calculated confidence intervals. Errors were relatively high for the number of births of cats and dogs.

\section{CONCLUSION}

Demographic parameters such as those estimated in this research, support the construction of population management indicators. They also help to identify targets for population management and in the case of Votorantim, it was found that possible targets are the proportion of semi-restricted animals, the availability of free reproductive programs and the prevention of situations reported as reasons that would lead to abandonment. Sample designs to specify in advance the expected error of estimated are needed to avoid useless estimates.

\section{ACKNOWLEDGMENTS}

The authors would like to thank the Center for Zoonosis Control of Votorantim for their collaboration with fieldwork and to the Fundação de Amparo à Pesquisa do Estado de São Paulo (FAPESP) for their financial support.

\section{ETHICS COMMITTEE AND BIOSECURITY}

The research was approved by the ethical committee on animal experimentation from the Veterinary Medicine and Animal Science Faculty of the University of São Paulo, protocol 2359/2011. 


\section{REFERENCES}

ACOSTA-JAMETT, G. et al. Demography of domestic dogs in rura and urban areas of the Coquimbo region of Chile and implications for disease transmission. Preventive Veterinary Medicine, v.94, n.3-4, p.272-281, 2010. Available form: <http://www. sciencedirect.com/science/article/pii/S016758771000005X> Accessed: May 11, 2015. doi: 10.1016/j.prevetmed.2010.01.002.

CANATTO, B.D. et al. Caracterização demográfica das populações de cães e gatos supervisionados do município de São Paulo. Arquivo Brasileiro de Medicina Veterinária e Zootecnia, v.64, n.6, p.1515-1523, 2012. Available from: <http://www.scielo. br/scielo.php?pid $=$ S0102-09352012000600017\& $\mathrm{script}=$ sci arttext>. Accessed: May 11, 2015. doi: 10.1590/S010209352012000600017.

CARTER, C.N. Pet population control: another decade without solutions?. Journal of the American Veterinary Medical Association, v.197, n.2, p.192-195, 1990.

CASEY, R.A. et al. Reasons for relinquishment and return of domestic cats (Felis Silvestris Catus) to Rescue Shelters in the UK. Anthrozoos: A Multidisciplinary Journal of The Interactions of People \& Animals, v.22, n.4, p.347-358, 2009.

DAVLIN, S.L.; VONVILLE, H.M. Canine rabies vaccination and domestic dog population characteristics in the developing world: a systematic review. Vaccine, v.30, n.24, p.3492-502, 2012. Available from: <http:/www.sciencedirect.com/science/article/pii/ S0264410X12004616>. Accessed: May 11, 2015. doi: 10.1016/j. vaccine.2012.03.069

DIESEL, G. et al. Factors affecting the success of rehoming dogs in the UK during 2005. Preventive Veterinary Medicine, v.84, n.3-4, p.228-241, 2008. Available from: $<$ http://www.sciencedirect. com/science/article/pii/S0167587707002516>. Accessed: May 11, 2015. doi: 10.1016/j.prevetmed.2007.12.004

DOWNES, M. et al. Demography of the pet dog and cat population on the island of Ireland and human factors influencing pet ownership. Preventive Veterinary Medicine, v.92, n.1-2, p.140-149, 2009. Available from: <http://www.sciencedirect.com/ science/article/pii/S0167587709002062>. Accessed: May 11, 2015. doi: 10.1016/j.prevetmed.2009.07.005.

ELLIOTT, R. et al. The Greyhound Adoption Program (GAP) in Australia and New Zealand: a survey of owners' experiences with their greyhounds one month after adoption. Applied Animal Behaviour Science, v.124, n.3-4, p.121-135, 2010. Available from: $<$ http://www.sciencedirect.com/science/article/pii/ S0168159110000705>. Accessed: May 11, 2015. doi: 10.1016/j. applanim.2010.02.006

FERREIRA, F. Avaliação do impacto das esterilizações e/ou sacrificio no controle de populaçõoes de cãaes através de um método matricial de crescimento populacional. 2010 . $93 \mathrm{p}$ Thesis (Livre Docência) - Epidemiologia Experimental Aplicada às Zoonoses. Universidade de Sao Paulo.

FOURNIER, A.; GELLER, E. Behavior analysis of companionanimal overpopulation: A conceptualization of the problem and suggestions for intervention. Behavior and Social Issues, v.13, p.51-68, 2004. Available from: $<$ http://journals.uic.edu/ojs/index php/bsi/article/view/35>. Accessed: May 11, 2015. doi: 10.5210/ bsi.v13i1.35.
GARCIA, R. Estudo da dinâmica populacional canina e felina e avaliação de ações para o equilíbrio dessas populações em área da cidade de São Paulo, SP, Brasil. 2009. 265p.Thesis (Doctorate) - Epidemiologia Experimental Aplicada às Zoonoses. Universidade de São Paulo, SP.

IBGE. Censo Demográfico 2010 - Agregado por setores censitário do universo. Available from: <http://www.ibge.gov.br>. Accessed: Oct. 10, 2014

KITALA, P. et al. Dog ecology and demography information to support the planning of rabies control in Machakos District, Kenya. Acta tropica, v.78, n.3, p.217-230, 2001. Available from: $<\mathrm{http} / /$ www.sciencedirect.com/science/article/pii/S0001706X01000821>. Accessed: May 11, 2105. doi: 10.1016/S0001-706X(01)00082-1.

LUMLEY, T. Survey sampling, a guide to analysis using $\mathbf{R}$. New Yersey: John Wiley and Sons, 2010. 275p.

MILLER, D.D. et al. Factors associated with the decision to surrender a pet to an animal shelter. Journal of the American Veterinary Medical Association, v.209, n.4, p.738-742, 1996.

NEW, J.C. et al. Moving: characteristics of dogs and cats and those relinquishing them to 12 U.S. animal shelters. Journal of applied animal welfare science: JAAWS, v. 2, n. 2, p. 83 95, 1999. Available from: <http://www.tandfonline.com/doi/ abs/10.1207/s15327604jaws0202 1?url ver=Z39.88-2003\&rfr $\mathrm{id}=$ ori:rid:crossref.org $\& \mathrm{rfr}$ dat $=\mathrm{cr}$ pub $\% 3 \mathrm{dpubmed}>$. Accessed: May 11, 2015. doi: $10.120 \overline{7} / \mathrm{s} 15327604$ jaws0202_1.

NEW, J. et al. Characteristics of shelter-relinquished animals and their owners compared with animals and their owners in U.S. Pet-Owning households. Journal of Applied Animal Welfare Science, v.3, n.3, p.179-201, 2000. Available from: <http://www.naiaonline.org/ uploads/WhitePapers/CharacteristicsOfShelterRelinquishedAnimals. pdf $>$. Accessed: May 11, 2015.

PATRONEK, G.J. et al. Risk factors for relinquishment of dogs to an animal shelter. Journal of the American Veterinary Medical Association, v.209, n.3, p.572-581, 1996.

PULCZER, A.S. et al. Owned dog demography in Todos Santos Cuchumatán, Guatemala. Preventive Veterinary Medicine, v.108, n.2-3, p.209-217, 2013. Available from: <http://www. sciencedirect.com/science/article/pii/S0167587712002371>. Accessed: May 11, 2015. doi: 10.1016/j.prevetmed.2012.07.012.

R CORE TEAM. R: a language and environment for statistical computing. Vienna, Austria, 2015. Available from: <http:// www.r-project.org >. Accessed: May 11, 2105.

SANTOS BAQUERO, O. et al. capm: an R package for Companion Animal Population Management, 2015. Available from: <http:// oswaldosantos.github.io/capm>. Accessed: May 11, 2015

SCARLETT, J.M. Interface of epidemiology, pet population issues and policy. Preventive Veterinary Medicine, v.86, n.34, p.188-197, 2008. Available from: <http://www.sciencedirect. com/science/article/pii/S0167587708000524>. Accessed: may 11, 2015. doi:10.1016/j.prevetmed.2008.02.007

SLATER, M.R. et al. Cat and dog ownership and management patterns in central Italy. Preventive Veterinary Medicine, v.85, n.3-4, p.267-294, 2008. Available from: $<$ http://www.sciencedirect. com/science/article/pii/S0167587708000408>. Accessed: May 11, 2015. doi: 10.1016/j.prevetmed.2008.02.001.

THRUSFIELD, M. Veterinary epidemiology. 3.ed. Oxford: Wiley-Blackwell, 2007. 624p.

Ciência Rural, v.45, n.11, nov, 2015. 